\title{
Budidaya Tanaman Akar Wangi (Vetiveria zizanioides (L.) Nash) dalam Wadah: Pengaruh Jenis Media Tanam dan Jumlah Bibit
}

\section{Vetiver (Vetiveria zizanioides (L.) Nash) Cultivation in Container: Effect of Media Composition and Number of Seedling Planted}

\author{
Resti Putri Septyani, Sintho Wahyuning Ardie*, Slamet Susanto
}

Departemen Agronomi dan Hortikultura, Fakultas Pertanian, Institut Pertanian Bogor (Bogor Agricultural University), J1. Meranti, Kampus IPB Darmaga, Bogor 16680, Indonesia

Telp.\&Faks. 62-251-8629353 e-mail agronipb@indo.net.id

*Penulis untuk korespondensi: sinthoardie@gmail.com

Disetujui 24 Desember 2013/ Published Online 10 Januari 2014

\begin{abstract}
The objectives of this experiment were to determine the effect of media composition and the number of seedlings planted on the growth of hydroponically grown vetiver (Vetiveria zizanioides). Vetiver 'Verina 2' variety was grown in polybags in a greenhouse of the Cikabayan Bawah Experimental Farm (240 m above sea level) started from November 2012 to July 2013. This experiment was arranged in a randomized complete block design with two factors and five replications. The first factor was media composition ( $\mathrm{v} / \mathrm{v})$, consisted of three levels i.e. 100\% charchoal husk, charcoal husk : styrofoam (2:1), and charcoal husk : styrofoam (1:1). The second factor was the number of seedlings in one polybag consisted of one seedling and two seedlings. The results showed that there were no interaction effects of media composition and number of seedlings planted to plant growth and root growth of vetiver. Plants grown in charcoal husk : styrofoam (1:1) medium had significantly higher number of plants per cluster, higher number of leaves, higher chlorophyll and carotenoid contents, higher number of roots, and longer primary roots than those in other media compositions. Planting two seedlings per polybag resulted in higher number of plant per cluster, higher number of leaves, higher shoot fresh and dry weight, and higher number of roots than one seedlings per polybag. These results showed that planting two seedlings in polybag containing charcoal husk : styrofoam (1:1) resulted in the best vegetative growth and root growth of vetiver.
\end{abstract}

Keywords: cultivation in container, number of seedling, media, vetiver

\section{ABSTRAK}

Penelitian ini bertujuan untuk mengetahui pengaruh komposisi media tanam dan jumlah bibit dalam budidaya tanaman akar wangi (Vetiveria zizanioides) secara hidroponik menggunakan polybag terhadap pertumbuhan tanaman akar wangi varietas Verina 2. Penelitian dilakukan di rumah kaca Kebun Percobaan Cikabayan Bawah, IPB dengan elevasi $240 \mathrm{~m}$ di atas permukaan laut (dpl) mulai dari bulan November 2012 hingga Juli 2013. Penelitian disusun berdasarkan rancangan kelompok lengkap teracak (RKLT) dengan dua faktor dan lima ulangan. Faktor pertama adalah komposisi media tanam (v/v) yang terdiri atas tiga taraf, yaitu 100\% arang sekam, arang sekam : styrofoam (2:1), dan arang sekam : styrofoam (1:1). Faktor kedua adalah jumlah bibit dalam satu polybag yang terdiri atas dua taraf yaitu satu bibit dan dua bibit. Hasil penelitian menunjukkan bahwa interaksi antara komposisi media tanam dan jumlah bibit per polybag tidak berpengaruh nyata terhadap pertumbuhan tanaman dan pertumbuhan akar tanaman akar wangi. Tanaman yang ditanam pada media arang sekam : styrofoam (1:1) memiliki jumlah daun, jumlah anakan, jumlah akar, panjang akar, kandungan klorofil, dan karotenoid yang lebih tinggi dibandingkan tanaman yang ditanam pada media lainnya. Penanaman dua bibit per polybag menghasilkan jumlah daun, jumlah anakan, bobot basah dan kering tajuk, dan jumlah akar yang lebih tinggi dibandingkan dengan satu bibit per polybag. Hasil tersebut menunjukkan bahwa penanaman dua bibit per polybag pada media arang sekam : styrofoam (1:1) menghasilkan pertumbuhan vegetatif dan pertumbuhan akar terbaik pada tanaman akar wangi. 
.Kata kunci: akar wangi, budidaya dalam wadah, jumlah bibit, media

\section{PENDAHULUAN}

Tanaman akar wangi (Vetiveria zizanioides (L.) Nash) merupakan anggota famili Graminae penghasil minyak atsiri penting di dunia. Indonesia merupakan salah satu dari tiga produsen minyak akar wangi dunia dan pada saat ini kebutuhan minyak akar wangi dunia mencapai 300 ton tiap tahun. Akan tetapi, Indonesia hanya mampu memenuhi sekitar $28 \%$ saja dari kebutuhan minyak akar wangi dunia (Mulyati et al., 2009). Hal tersebut dikarenakan produktivitas akar wangi yang masih rendah. Rendemen minyak akar wangi yang sangat rendah yaitu $1.5-2 \%$ bobot kering, semakin menghambat peningkatan ekspor minyak akar wangi (Sani, 2011). Belum terstandarnya mutu minyak akar wangi yang dihasilkan oleh petani Indonesia juga menyebabkan harga minyak akar wangi yang sangat fluktuatif (Kardinan, 2005). Usaha peningkatan produksi dan kualitas minyak akar wangi dapat dilakukan dengan perbaikan teknologi budidaya akar wangi. Dalam perbaikan teknik budidaya, kegiatan pemanenan merupakan tahap penting yang menentukan hasil minyak akar wangi berkualitas tinggi. Kehilangan hasil pada proses pasca panen primer (pencucian dan pengeringan) dapat mencapai 65\% (Mulyono et al., 2012). Nilai kehilangan hasil tersebut belum memperhitungkan kehilangan hasil akibat tertinggalnya akar di dalam tanah pada saat pemanenan. Untuk menanggulangi kendala tersebut diperlukan suatu teknologi budidaya yang tepat guna.

Salah satu teknologi budidaya yang dapat digunakan adalah teknologi hidroponik. Hidroponik merupakan satu teknik budidaya tanaman tanpa menggunakan tanah sebagai media tumbuh tetapi menggunakan media inert seperti kerikil, pasir, gravel, arang sekam, peat, vermiculite, styrofoam, atau sawdust yang diberi larutan nutrisi (Resh, 2004). Penelitian ini menggunakan dua jenis media tanam yaitu arang sekam dan styrofoam. Hardjanti (2005) mengungkapkan bahwa kelebihan penggunaan arang sekam dan styrofoam adalah sama-sama memiliki porositas yang baik bagi perkembangan akar, ringan, dan gembur sehingga tidak menghambat pertumbuhan akar. Menurut Ermina (2010) kekurangan dari penggunaan arang sekam dan styrofoam adalah sama-sama memiliki kandungan hara yang rendah, sehingga kebutuhan hara tanaman perlu disuplai $100 \%$. Penggunaan teknologi hidroponik dalam budidaya tanaman akar wangi diharapkan dapat menekan kehilangan hasil pada proses pemanenan. Pemanfaatan arang sekam dan styrofoam sebagai media tanam dalam teknologi hidroponik diharapkan menjadi media tanam alternatif selain tanah, sehingga dapat mengurangi masalah limbah yang melimpah dari sektor pertanian dan non pertanian. Penelitian ini difokuskan pula untuk mendapatkan informasi mengenai jumlah bibit yang sesuai bagi pertumbuhan dan hasil akar wangi, sehingga dapat meningkatkan efisiensi input yang dibutuhkan untuk budidaya akar wangi tetapi dengan tetap menghasilkan produksi akar wangi yang tinggi. Aplikasi teknologi hidroponik pada tanaman akar wangi diharapkan dapat menjadi salah satu solusi untuk mendapatkan akar wangi bermutu tinggi dengan input yang seminimal mungkin namun output yang maksimal dengan pemanenan yang mudah.

Secara umum penelitian ini bertujuan memperoleh teknik budidaya dalam wadah untuk tanaman akar wangi sehingga dapat memudahkan proses panen dan menghasilkan biomassa akar dengan kandungan bahan aktif yang tinggi. Secara khusus penelitian ini bertujuan untuk mengetahui pengaruh jenis media tanam dan jumlah bibit dalam budidaya tanaman akar wangi yang ditanam secara hidroponik menggunakan polybag terhadap pertumbuhan dan hasil tanaman akar wangi varietas Verina 2.

\section{BAHAN DAN METODE}

Penelitian ini dilaksanakan di rumah kaca Kebun Percobaan Cikabayan Bawah, University Farm, Fakultas Pertanian IPB dengan elevasi 240 $m$ di atas permukaan laut (dpl). Kegiatan penelitian berlangsung selama sembilan bulan mulai dari bulan November 2012 hingga Juli 2013. Persiapan penelitian membutuhkan waktu tiga bulan untuk persiapan bibit dan fasilitas percobaan.

Penelitian ini disusun berdasarkan rancangan kelompok lengkap teracak (RKLT) dua faktor. Faktor pertama adalah komposisi media tanam (v/v) dengan tiga taraf, yaitu 100\% arang sekam, arang sekam : styrofoam (2:1), dan arang sekam : styrofoam (1:1). Faktor kedua adalah jumlah bibit dalam satu polybag yang terdiri atas dua taraf yaitu satu bibit dan dua bibit. Percobaan terdiri atas enam kombinasi dengan lima ulangan sehingga terdapat 30 satuan percobaan. Tiap satu 
satuan percobaan terdiri atas polybag berukuran $60 \mathrm{~cm} \times 70 \mathrm{~cm}$. Data yang diperoleh dianalisis menggunakan uji $\mathrm{F}$ dengan perangkat lunak SAS 9.1.3. Jika terdapat pengaruh nyata, maka dilakukan uji lanjut menggunakan Duncan Multiple Range Test (DMRT) pada taraf $\alpha=5 \%$.

Bibit akar wangi varietas Verina 2 berupa anakan yang diperoleh dari Balai Penelitian Tanaman Rempah dan Obat (Balittro) diperbanyak dan diadaptasikan dengan lingkungan tumbuh sebelum digunakan dalam percobaan. Persiapan bibit meliputi pemisahan bibit menjadi satu anakan, pemangkasan daun, dan penanaman dalam polybag berisi kompos. Selama pemeliharaan, bibit dipupuk dengan pupuk NPK mutiara 16:16:16 setiap satu minggu sekali dengan konsentrasi $15 \mathrm{~g} \mathrm{l}^{-1}$. Bibit dipelihara di dalam rumah naungan hingga 11 minggu setelah tanam (MST). Bibit dengan jumlah daun 10 - 40 helai dipangkas hingga tingginya seragam, yaitu $30 \mathrm{~cm}$. Bibit kemudian dipindahtanamkan ke dalam polybag berukuan $60 \mathrm{~cm} \quad \times \quad 70 \mathrm{~cm}$. Perlakuan komposisi media tanam $100 \%$ arang sekam disiapkan dengan cara mengisi polybag dengan $8.5 \mathrm{~kg}$ arang sekam, sedangkan perlakuan komposisi media tanam arang sekam : styrofoam $(2: 1)(\mathrm{v} / \mathrm{v})$ disiapkan dengan cara mengisi polybag dengan $6.4 \mathrm{~kg}$ arang sekam dan $0.4 \mathrm{~kg}$ styrofoam. Perlakuan komposisi media tanam arang sekam : styrofoam (1:1) (v/v) disiapkan dengan cara mengisi polybag dengan $4.3 \mathrm{~kg}$ arang sekam dan $0.4 \mathrm{~kg}$ styrofoam. Jumlah bibit akar wangi ditanam ke dalam polybag sesuai dengan perlakuan. Polybag diletakkan dalam lima baris di dalam rumah kaca dengan jarak $30 \mathrm{~cm}$ antar polybag. Pada tiap polybag ditancapkan dua buah emiter irigasi tetes sebagai jalur fertigasi. Fertigasi dilakukan dengan frekuensi 2 kali/hari dengan volume siram $1000 \mathrm{ml} /$ tiap kali siram pada pukul 10.00 WIB dan 13.00 WIB. Penyiraman secara manual juga dilakukan sebanyak 2 kali/hari dengan volume siram $1000 \mathrm{ml} /$ polybag pada pukul 07.00 WIB dan 16.00 WIB. Komposisi larutan hara yang digunakan mengacu pada Yoshida et al. (1979) dengan beberapa modifikasi. Komponen hara terdiri atas $\mathrm{N}$ (102.5 ppm), $\mathrm{P}$ (31.9 ppm), K (80.6 ppm), Ca (118.9 ppm), Mg (45.5 ppm), S (83.2 ppm), Fe (5 ppm), Mn (1.3 ppm), Zn (0.3 ppm), Cu (0.1 ppm), Mo (0.3 $\mathrm{ppm})$, dan $\mathrm{B}$ (1 ppm). Kisaran $\mathrm{pH}$ larutan hara adalah $5-6$.

Pemeliharaan tanaman yang dilakukan meliputi penyiraman rutin, sanitasi lingkungan tumbuh, serta pengendalian hama secara manual.
Pada minggu ke-20 setelah perlakuan atau pada saat sebagian besar tanaman sudah memiliki lebih dari tiga anakan, dilakukan pengambilan contoh destruktif sebanyak tiga ulangan dengan cara membuka polybag agar tidak ada akar yang tertinggal. Sisa tanaman (dua ulangan) tetap dipelihara hingga pertumbuhan tanaman (massa akar) tidak dapat ditopang lagi oleh media tanam yang digunakan (maksimal sampai 12 bulan setelah perlakuan/BSP).

Pengamatan pertumbuhan vegetatif tanaman dilakukan setiap satu minggu sekali yaitu pada (1) tinggi tanaman $(\mathrm{cm})$ yang dilakukan dengan pengukuran dari pangkal tanaman (pada permukaan media) sampai bagian ujung rumpun tanaman terpanjang, (2) jumlah daun (helai) dilakukan dengan menghitung daun yang sudah terbuka sempurna, (3) saat muncul anakan pertama (HST) dilakukan dengan melihat saat anakan muncul pertama kali, (4) jumlah anakan dilakukan sesuai jumlah anakan yang muncul. Kuantifikasi kehijauan daun diamati pada minggu 2, 5, dan 7 setelah perlakuan dengan alat SPAD (soil plant analysis development). Kandungan klorofil daun (klorofil a, b, dan klorofil total), karotenoid dan antosianin dianalisis pada minggu ke-6 setelah perlakuan dengan alat spektrofotometer UV menggunakan metode Sims dan Gamon (2002). Pada minggu ke-16 setelah perlakuan dilakukan pengurangan frekuensi irigasi menjadi hanya penyiraman secara manual sebanyak 2 kali/hari dengan volume siram 1000 $\mathrm{ml} /$ polybag pada pukul 07.00 WIB dan 16.00 WIB. Pada minggu tersebut juga dilakukan pemangkasan tajuk hingga menyisakan tinggi tajuk $30 \mathrm{~cm}$ untuk kemudian dilakukan pengamatan bobot basah dan bobot kering tajuk. Bobot basah tajuk (g) ditimbang dengan menggunakan timbangan analitik setelah pemangkasan, dan (2) bobot kering tajuk (g) dilakukan dengan menimbang tajuk setelah dikeringkan menggunakan oven selama 24 jam pada suhu $80^{\circ} \mathrm{C}$. Pengamatan minggu ke-20 pada pemanenan destruktif meliputi (1) panjang akar $(\mathrm{cm})$ diukur dengan menggunakan penggaris dari pangkal akar hingga ujung akar terpanjang, (2) jumlah akar besar (buah) dihitung berdasarkan jumlah akar dengan diameter $>3 \mathrm{~mm}$ yang muncul, (3) jumlah akar kecil (buah) dihitung berdasarkan jumlah akar dengan diameter $<3 \mathrm{~mm}$ yang muncul, (4) jumlah akar baru dihitung berdasarkan jumlah akar yang baru muncul berwarna putih tanpa adanya akar tersier, (5) jumlah akar total (buah) dihitung berdasarkan akar besar dijumlahkan dengan akar kecil, (6) diameter 
akar total $(\mathrm{cm})$ diukur dengan menggunakan jangka sorong pada bagian tengah total akar.

Pengamatan lingkungan dalam rumah kaca dilakukan terhadap suhu $\left({ }^{\circ} \mathrm{C}\right)$ dan kelembaban $(\%)$ rata-rata harian menggunakan termo-hygrometer bola basah-bola kering. Data suhu dan kelembaban yang diperoleh kemudian dibuat menjadi rata-rata suhu dan kelembaban harian (Tjasyono 2004). Kondisi larutan hara dimonitor dengan mengukur $\mathrm{pH}$ menggunakan $\mathrm{pH}$ meter portable AD-110 dan EC menggunakan EC meter portable AD-310 setiap satu bulan sekali.

\section{HASIL DAN PEMBAHASAN}

Parameter iklim mikro yang diamati selama penelitian berlangsung adalah intensitas radiasi matahari, suhu, dan kelembaban udara harian di dalam rumah kaca. Secara umum, intensitas radiasi matahari tertinggi yang diperoleh dari (Badan Meteorologi Klimatologi dan Geofisika) BMKG Dramaga dicapai pada saat 4, 5, 6, 7 MSP sekitar $1.5 \times 10^{-7}$ MJ.cm ${ }^{-2} .10^{-3}$ (Gambar 1A). Suhu rata-rata di dalam rumah kaca pada bulan November 2012 hingga Juli 2013 saat penelitian cukup tinggi, yaitu $30.0{ }^{\circ} \mathrm{C}$. Rata-rata suhu dan kelembaban udara pada pagi hari (08.00 WIB) adalah $27.0{ }^{\circ} \mathrm{C}$ dan $83.5 \%$, siang (12.00 WIB) $35.6{ }^{\circ} \mathrm{C}$ dan $69.2 \%$, dan pada sore hari $(17.00$ WIB) $27.8{ }^{\circ} \mathrm{C}$ dan $82.2 \%$. Kondisi suhu dan kelembaban udara rumah kaca cenderung stabil dan sefluktuatif intensitas radiasi matahari (Gambar 1B).
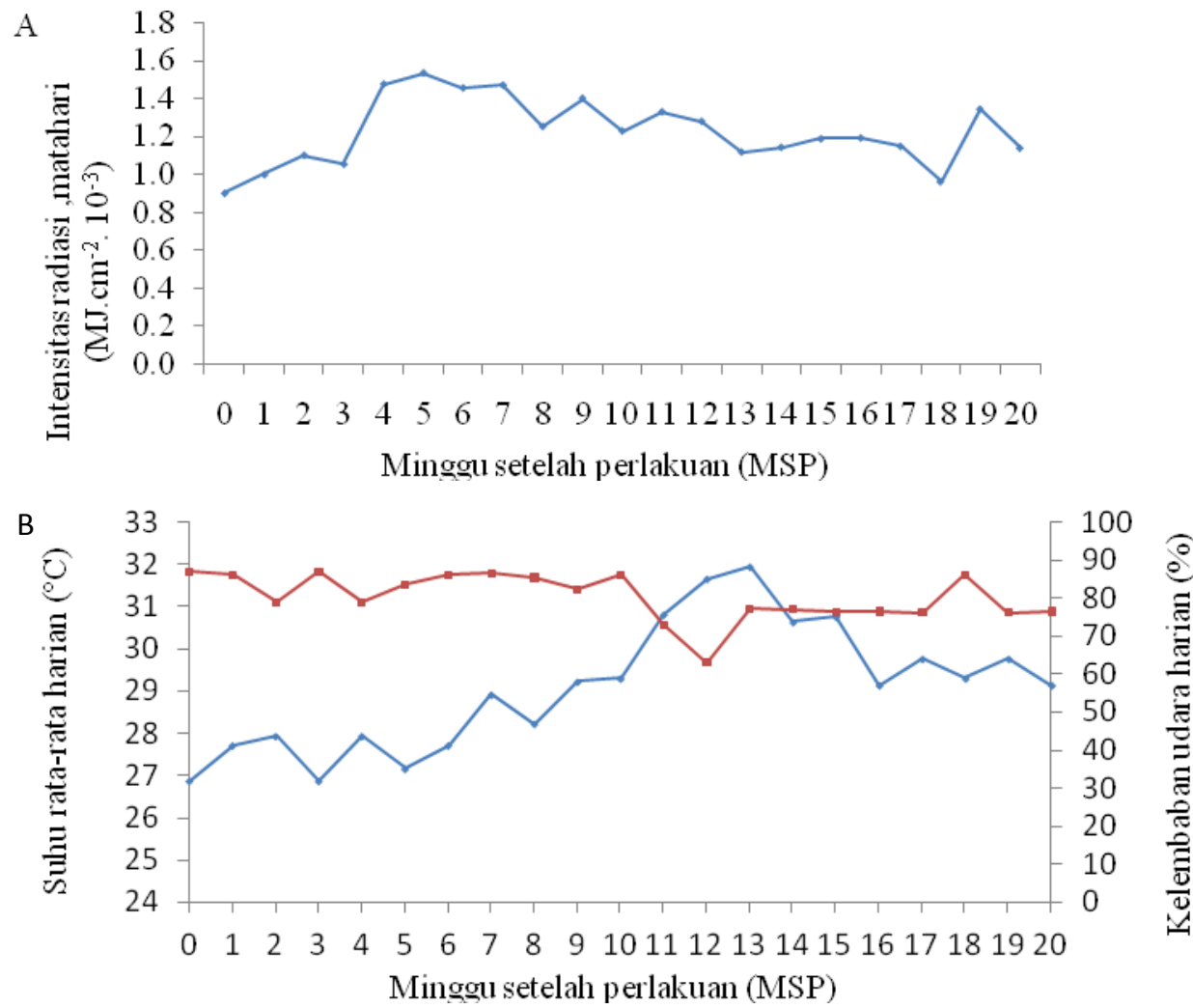

Gambar 1. Intensitas radiasi matahari (A), suhu rata-rata harian rumah kaca ( $\square$ ) \& kelembaban udara harian rumah kaca $(\diamond)(\mathrm{B})$ lingkungan saat penelitian

Handoko (2009) menjelaskan bahwa intensitas radiasi matahari dapat menyebabkan pemanasan udara di atas permukaan bumi dan menyebabkan terjadinya penguapan. Peningkatan penguapan dapat menyebabkan nisbah kelembaban di udara menjadi tinggi. Struktur bangunan rumah kaca yang berfungsi mengurangi intensitas radiasi matahari berlebihan inilah yang menyebabkan kelembaban udara dan suhu di dalam rumah kaca menjadi cenderung stabil. Menurut Kartasapoetra (2008) dan Suhardiyanto (2009) kestabilan suhu di dalam rumah kaca disebabkan karena sistem konstruksi dan kaca pada rumah kaca yang menjaga fluktuasi suhu di dalam rumah kaca menjadi lebih stabil dibandingkan dengan di luar rumah kaca. 
Menurut Surtiningsih (2009) akar wangi dapat tumbuh dengan baik pada kisaran suhu 17 $27{ }^{\circ} \mathrm{C}$. Meskipun pada beberapa kondisi suhu rumah kaca melebihi suhu optimum pertumbuhan tanaman akar wangi, namun kondisi lingkungan di dalam rumah kaca selama penelitian ini cukup sesuai bagi pertumbuhan tanaman akar wangi. Hal tersebut ditunjukkan oleh pertumbuhan tanaman akar wangi terus meningkat hingga 16 MSP (data tidak ditampilkan).

Penelitian ini menunjukkan bahwa interaksi antara komposisi media tanam dan jumlah bibit per polybag tidak berpengaruh nyata terhadap pertumbuhan tanaman dan pertumbuhan akar tanaman akar wangi (Tabel 1). Komposisi media tanam berpengaruh terhadap parameter jumlah daun, jumlah anakan, jumlah akar, panjang akar, kandungan klorofil dan karotenoid daun tanaman akar wangi. Jumlah bibit menunjukkan pengaruh nyata terhadap parameter jumlah daun, jumlah anakan, jumlah akar, bobot basah dan kering tajuk tanaman akar wangi.

Tabel 1. Rekapitulasi sidik ragam pengaruh komposisi media tanam dan jumlah bibit per polybag terhadap karakter agronomi dan fisiologi tanaman akar wangi

\begin{tabular}{|c|c|c|c|c|}
\hline Parameter & Umur tanaman (MSP) & $\begin{array}{l}\text { Media } \\
\text { tanam }\end{array}$ & $\begin{array}{c}\text { Jumlah } \\
\text { bibit }\end{array}$ & $\begin{array}{c}\text { Jumlah bibit } * \\
\text { media tanam }\end{array}$ \\
\hline \multicolumn{5}{|l|}{ A. Karakter agronomi: } \\
\hline Tinggi tanaman $(\mathrm{cm})$ & 16 & th & $\operatorname{tn}$ & th \\
\hline Saat muncul anakan pertama (HST) & 16 & tn & tn & tn \\
\hline Jumlah daun (helai) & 16 & ** & ** & tn \\
\hline Jumlah anakan & 16 & $* *$ & $* *$ & tn \\
\hline Bobot basah tajuk (g) & 16 & $\operatorname{tn}$ & * & tn \\
\hline Bobot kering tajuk (g) & 16 & $\operatorname{tn}$ & * & tn \\
\hline Akar besar (unit) & 20 & $* *$ & $* *$ & tn \\
\hline Akar kecil (unit) & 20 & $* *$ & $* *$ & tn \\
\hline Akar total (unit) & 20 & $* *$ & $* *$ & tn \\
\hline Akar baru (unit) & 20 & $\operatorname{tn}$ & tn & tn \\
\hline Panjang akar (cm) & 20 & $* *$ & tn & tn \\
\hline Diameter akar $(\mathrm{cm})$ & 20 & $\operatorname{tn}$ & tn & $\operatorname{tn}$ \\
\hline \multicolumn{5}{|l|}{ B. Karakter fisiologi: } \\
\hline \multirow[t]{3}{*}{ Warna daun } & 2 & $\operatorname{tn}$ & $\operatorname{tn}$ & tn \\
\hline & 7 & tn & $\operatorname{tn}$ & tn \\
\hline & 15 & $\operatorname{tn}$ & tn & tn \\
\hline Klorofil a & 6 & $*$ & tn & tn \\
\hline Klorofil b & 6 & $* *$ & tn & tn \\
\hline Klorofil total & 6 & $*$ & tn & tn \\
\hline Antosianin & 6 & tn & tn & tn \\
\hline Karotenoid & 6 & tn & tn & tn \\
\hline
\end{tabular}

Keterangan: ${ }^{* *}=$ berbeda sangat nyata pada taraf $\alpha=1 \%, *=$ berbeda nyata pada taraf $\alpha=5 \%$, th $=$ tidak berbeda nyata.

Pengaruh Media Tanam terhadap Pertumbuhan Tanaman Akar Wangi

Media tanam berpengaruh sangat nyata terhadap jumlah anakan dan jumlah daun tanaman akar wangi pada 16 MSP, namun tidak berpengaruh nyata terhadap tinggi tanaman, saat muncul anakan pertama, bobot basah dan kering tajuk pada 16 MSP (Tabel 2). Perkembangan tanaman akar wangi ditandai dengan munculnya anakan yang merupakan salah satu cara perbanyakan tanaman. Media tanam arang sekam : styrofoam (1:1) menghasilkan ratarata jumlah anakan yang lebih tinggi dibandingkan dengan media arang sekam 100\%, namun tidak berbeda dibandingkan dengan media arang sekam : styrofoam (2:1). Rata-rata saat muncul anakan pertama pada semua perlakuan media adalah 4 - 6 hari setelah tanam (HST). Semakin banyak jumlah anakan, maka jumlah daun juga akan semakin tinggi. Jumlah daun tanaman akar wangi yang ditanam pada media 
arang sekam : styrofoam (1:1) juga lebih tinggi maupun arang sekam : styrofoam (2:1). dibandingkan dengan media arang sekam 100\%

Tabel 2. Pengaruh media tanam terhadap tinggi tanaman, saat muncul anakan pertama, jumlah daun, dan jumlah anakan, bobot basah dan kering tajuk pada 16 MSP

\begin{tabular}{lcccccc}
\hline Media tanam & $\begin{array}{c}\text { Tinggi } \\
\text { tanaman } \\
(\mathrm{cm})\end{array}$ & $\begin{array}{c}\text { Saat muncul } \\
\text { anakan pertama } \\
(\text { HST })\end{array}$ & $\begin{array}{c}\text { Jumlah } \\
\text { anakan } \\
\text { (anakan) }\end{array}$ & $\begin{array}{c}\text { Jumlah } \\
\text { daun } \\
\text { (helai) }\end{array}$ & $\begin{array}{c}\text { Bobot } \\
\text { basah } \\
\text { tajuk }(\mathrm{g})\end{array}$ & $\begin{array}{c}\text { Bobot } \\
\text { kering } \\
\text { tajuk }(\mathrm{g})\end{array}$ \\
\hline Arang sekam 100\% & 185.1 & 6.0 & $36.8 \mathrm{~b}$ & $247.5 \mathrm{~b}$ & 213.4 & 44.8 \\
Arang sekam : styrofoam $(2: 1)$ & 190.3 & 4.8 & $43.0 \mathrm{~b}$ & $285.6 \mathrm{ab}$ & 238.4 & 50.5 \\
Arang sekam : styrofoam $(1: 1)$ & 182.6 & 4.8 & $50.0 \mathrm{a}$ & $333.6 \mathrm{a}$ & 289.8 & 62.4 \\
\hline
\end{tabular}

Keterangan: Angka pada kolom yang sama yang diikuti huruf yang sama menunjukkan hasil yang tidak berbeda nyata berdasarkan DMRT pada taraf $\alpha=5 \%$.

Jumlah anakan dan jumlah daun pada media arang sekam : styrofoam $(1: 1)$ yang lebih tinggi dibandingkan pada perlakuan lain diduga disebabkan oleh perbedaan sifat fisik media. Santoso et al. (2011) menyatakan bahwa styrofoam terbuat dari bahan copolimer stryen yang tidak mengandung hara namun mempunyai bobot yang sangat ringan yaitu $13 \mathrm{~kg} / \mathrm{m}^{3}-15 \mathrm{~kg}$ $\mathrm{m}^{3-1}$. Styrofoam memiliki bobot yang lebih ringan dibandingkan dengan arang sekam yaitu $125 \mathrm{~kg}$ $\mathrm{m}^{3-1}$. Sifat media styrofoam yang ringan membuat campuran media antara arang sekam dan styrofoam memiliki pori-pori media yang besar. Pori-pori besar yang dimiliki oleh media arang sekam : styrofoam (1:1) memungkinkan akar berkembang dengan baik sehingga menghasilkan tanaman yang lebih baik pertumbuhannya dibandingkan dengan media arang sekam $100 \%$. Suryanto dan Dwi (2010) melaporkan bahwa kekurangan dari media arang sekam adalah media tersebut lebih mudah hancur dan lapuk karena adanya proses dekomposisi secara terus menerus yang pada akhirnya akan membuat media arang sekam menjadi lebih padat. Diduga pemadatan pada media arang sekam $100 \%$ ini menyebabkan pori-pori media mengecil. Pori arang sekam yang mengecil menyebabkan akar sulit menembus media untuk melakukan penyerapan air dan hara sehingga kebutuhan tanaman akan nutrisi tidak tercukupi yang mengakibatkan proses fotosintesis dan petumbuhan tanaman terhambat. Sebaliknya pada media arang sekam : styrofoam (1:1), struktur styrofoam tidak mengalami perubahan dari awal hingga akhir perlakuan. Campuran media arang sekam : styrofoam (1:1) memberikan hasil yang paling baik bagi pertumbuhan akar wangi. Menurut Ginting (2008) penggunaan media campuran cenderung mendorong pertumbuhan tanaman menjadi lebih baik dibandingkan dengan hanya satu media. Penggunaan media campuran dapat memperbaiki kekurangan sifat dari masing-masing bahan yaitu kecepatan pelapukan, tingkat tersedianya hara, dan kondisi kelembaban dalam media tanam. Selain dipengaruhi oleh sifat fisik media, pertumbuhan tanaman yang lebih baik pada media arang sekam : styrofoam (1:1) diduga karena tanaman pada media tersebut menyerap hara lebih tinggi dibandingkan pada perlakuan lainnya. Hal tersebut tampak dari nilai EC (electrical conductivity) media arang sekam : styrofoam (1:1) yang lebih rendah dibandingkan media arang sekam $100 \%$ pada 8 MSP (Tabel 3). Rata-rata nilai EC larutan hara yang diaplikasikan ke tiap media adalah $512 \mathrm{ppm}$. Penurunan EC media seiring dengan tumbuhnya tanaman diduga menggambarkan bahwa sebagian hara yang diaplikasikan telah diserap oleh tanaman.

Tabel 3. Pengaruh media tanam terhadap nilai EC

\begin{tabular}{lccc}
\hline \multicolumn{1}{c}{ Media tanam } & \multicolumn{3}{c}{ EC (ppm) } \\
\cline { 2 - 4 } & $4 \mathrm{MSP}$ & $8 \mathrm{MSP}$ & $12 \mathrm{MSP}$ \\
\hline Arang sekam 100\% & 178.5 & $634.7 \mathrm{a}$ & 173.0 \\
Arang sekam : styrofoam $(2: 1)$ & 211.5 & $368.7 \mathrm{~b}$ & 181.7 \\
Arang sekam : styrofoam (1:1) & 231.2 & $340.2 \mathrm{~b}$ & 218.0 \\
\hline
\end{tabular}

Keterangan: Angka pada kolom yang sama yang diikuti huruf yang sama menunjukkan hasil yang tidak berbeda nyata berdasarkan DMRT pada taraf $\alpha=5 \%$. 
Media tanam berpengaruh nyata terhadap kandungan klorofil a, klorofil $b$, klorofil total dan karotenoid daun tanaman akar wangi pada 6 MSP, namun tidak berpengaruh nyata terhadap warna daun pada 7 MSP dan kandungan antosianin pada 6 MSP (Tabel 4). Media tanam arang sekam : styrofoam (2:1) menghasilkan rata-rata kandungan klorofil a, klorofil b, klorofil total, dan karotenoid yang lebih tinggi dibandingkan dengan media arang sekam $100 \%$, namun tidak berbeda dibandingkan dengan media arang sekam : styrofoam (1:1). Diduga penggunaan media campuran arang sekam dan styrofoam mampu mendukung proses metabolisme tanaman, termasuk pembentukan klorofil pada daun. Poripori media pada campuran arang sekam dan styrofoam yang ideal, memudahkan pergerakan akar dalam menyerap air dan hara sehingga kebutuhan tanaman akan hara tercukupi untuk proses fotosintesis di daun. Menurut Li et al. (2006) klorofil merupakan komponen kloroplas yang utama dan kandungan klorofil relatif berkorelasi positif dengan laju fotosintesis. Hasil penelitian Prihastanti (2010) menunjukkan bahwa pada tanaman kakao pembentukan klorofil akan berlangsung optimal apabila kondisi media mampu mendukung proses fisiologi tanaman, seperti ketersediaan air dan hara.

Tabel 4. Pengaruh media tanam terhadap warna daun pada 7 MSP dan kandungan klorofil daun pada 6 MSP

\begin{tabular}{lcccccc}
\hline \multicolumn{1}{c}{ Media tanam } & $\begin{array}{c}\text { Warna } \\
\text { daun }\end{array}$ & $\begin{array}{c}\text { Klorofil } \\
\text { total } \\
\ldots \ldots \ldots \ldots \ldots \ldots \ldots \ldots . \ldots \ldots \mathrm{mg} \mathrm{g}^{-1}\end{array}$ & $\begin{array}{c}\text { Klorofil a } \\
\text { daun segar............. }\end{array}$ & $\begin{array}{c}\text { Klorofil b } \\
\left(\mathrm{mmol} \mathrm{g}^{-1}\right)\end{array}$ \\
\hline Arang sekam 100\% & 40.3 & $1.4 \mathrm{~b}$ & $1.0 \mathrm{~b}$ & $0.4 \mathrm{~b}$ & $0.2 \mathrm{~b}$ & 0.3 \\
Arang sekam : styrofoam $(2: 1)$ & 42.2 & $2.7 \mathrm{a}$ & $2.0 \mathrm{a}$ & $0.7 \mathrm{a}$ & $0.5 \mathrm{a}$ & 0.4 \\
Arang sekam : styrofoam $(1: 1)$ & 42.6 & $2.5 \mathrm{a}$ & $1.8 \mathrm{a}$ & $0.7 \mathrm{a}$ & $0.4 \mathrm{a}$ & 0.4 \\
\hline
\end{tabular}

Keterangan: Angka pada kolom yang sama yang diikuti huruf yang sama menunjukkan hasil yang tidak berbeda nyata berdasarkan DMRT pada taraf $\alpha=5 \%$.

Media tanam berpengaruh nyata terhadap jumlah akar besar, akar kecil, akar total, dan panjang akar tanaman akar wangi pada 20 MSP, namun tidak berpengaruh nyata terhadap jumlah akar baru dan diameter akar pada 20 MSP (Tabel 5). Media tanam arang sekam : styrofoam (1:1) menghasilkan rata-rata jumlah akar besar, akar kecil, akar total, dan panjang akar yang lebih tinggi dibandingkan dengan media arang sekam 100\% maupun arang sekam : styrofoam (2:1). Media tanam dengan porositas tinggi dapat memacu pertumbuhan akar dibandingkan media dengan porositas rendah. Pelapukan arang sekam seiring berjalannya waktu (Suryanto dan Dwi, 2010) dapat menyebabkan penurunan porositas media dan menghambat perkembangan akar. Pertumbuhan akar tanaman pada media arang sekam : styrofoam (1:1) lebih tinggi dibandingkan pada media arang sekam $100 \%$ dikarenakan media lebih mudah ditembus oleh akar untuk pengambilan air dan hara dari dalam media. Oleh karena itu, keberadaan styrofoam dalam media tanam dapat membantu mempertahankan porositas media dan menunjang pertumbuhan akar.

Tabel 5. Pengaruh media tanam terhadap jumlah akar besar, akar kecil, akar total, akar baru, panjang akar, dan diameter akar pada 20 MSP

\begin{tabular}{lcccccc}
\hline \multicolumn{1}{c}{ Media tanam } & $\begin{array}{c}\text { Akar besar } \\
\text { (unit) }\end{array}$ & $\begin{array}{c}\text { Akar kecil } \\
\text { (unit) }\end{array}$ & $\begin{array}{c}\text { Akar total } \\
\text { (unit) }\end{array}$ & $\begin{array}{c}\text { Akar } \\
\text { baru } \\
\text { (unit) }\end{array}$ & $\begin{array}{c}\text { Panjang } \\
\text { akar } \\
\text { (cm) }\end{array}$ & $\begin{array}{c}\text { Diameter } \\
\text { akar } \\
(\mathrm{cm})\end{array}$ \\
\hline Arang sekam 100\% & $82.2 \mathrm{~b}$ & $44.3 \mathrm{~b}$ & $135.5 \mathrm{~b}$ & 3.3 & $110.5 \mathrm{~b}$ & 18.3 \\
Arang sekam : styrofoam $(2: 1)$ & $101.0 \mathrm{~b}$ & $43.8 \mathrm{~b}$ & $157.3 \mathrm{~b}$ & 3.6 & $133.3 \mathrm{a}$ & 18.7 \\
Arang sekam : styrofoam $(1: 1)$ & $144.3 \mathrm{a}$ & $80.0 \mathrm{a}$ & $248.5 \mathrm{a}$ & 4.7 & $153.3 \mathrm{a}$ & 18.2 \\
\hline
\end{tabular}

Keterangan: Angka pada kolom yang sama yang diikuti huruf yang sama menunjukkan hasil yang tidak berbeda nyata berdasarkan DMRT pada taraf $\alpha=5 \%$.

Salah satu fungsi utama akar adalah untuk menyerap air. Song (2005) melaporkan bahwa saat terjadi penurunan ketersediaan air maka tanaman akan memperluas area perakaran 
tanaman sehingga dapat meningkatkan efisiensi penyerapan air. Pemanjangan akar dapat meningkatkan efisiensi penyerapan air, sebaliknya pertumbuhan tajuk yang akan memperbesar proses transpirasi dan kehilangan air. Air dan hara yang diberikan pada media tanam akan ditahan dalam pori-pori media, sehingga berapa besar air dan hara yang dapat ditahan oleh media tergantung pada ukuran pori media tanam. Menurut Hardjanti (2005) arang sekam dan styrofoam merupakan media tanam yang samasama bersifat porous. Media tanam yang bersifat porous memungkinkan tanaman cepat mengalami kehilangan air akibat evaporasi dan drainase ke bawah karena besarnya pori makro yang dimiliki oleh media. Kehilangan air tanaman mengindikasikan terjadinya penurunan potensial air pada daun akibat penurunan kadar air media. Ketersediaan air merupakan salah satu cekaman abiotik yang dapat menghambat pertumbuhan suatu tanaman. Tanaman yang mengalami penurunan ketersediaan air, akan mengalami pertumbuhan akar yang lebih cepat, sedangkan pertumbuhan tajuk tertekan. Hal ini diperlukan untuk menjaga keseimbangan air dalam tubuh tanaman melalui reduksi permukaan daun dan mempertahankan perkembangan akarnya sehingga tanaman mampu menyuplai air dengan cukup.

\section{Pengaruh Jumlah Bibit terhadap Pertumbuhan Tanaman Akar Wangi}

Hasil penelitian menunjukkan bahwa terjadi kompetisi antar tanaman dalam satu polybag. Penanaman dua bibit per polybag menyebabkan jumlah daun, jumlah anakan, bobot basah, dan kering tajuk per individu tanaman yang lebih rendah dibandingkan pada penanaman satu bibit per polybag (Tabel 6).

Tabel 6. Pengaruh jumlah bibit terhadap jumlah daun, jumlah anakan, bobot basah dan kering tajuk per individu tanaman pada $16 \mathrm{MSP}$

\begin{tabular}{ccccc}
\hline Jumlah bibit & $\begin{array}{c}\text { Jumlah daun } \\
\text { (helai) }\end{array}$ & Jumlah anakan & $\begin{array}{c}\text { Bobot basah tajuk } \\
(\mathrm{g})\end{array}$ & $\begin{array}{c}\text { Bobot kering tajuk } \\
(\mathrm{g})\end{array}$ \\
\hline Satu bibit per polybag & 242.5 & 35.7 & 213.2 & 44.9 \\
Dua bibit per polybag & 167.6 & 25.4 & 140.6 & 30.1 \\
\hline Uji F & $* *$ & $* *$ & $* *$ & $* *$ \\
\hline
\end{tabular}

Keterangan: $* *=$ berbeda sangat nyata pada taraf $\alpha=1 \%$.

Walaupun terdapat kompetisi antar tanaman, penanaman dua bibit per polybag dapat menghasilkan total biomassa yang lebih tinggi dibandingkan dengan penanaman satu bibit per polybag. Penanaman dua bibit akar wangi per polybag menghasilkan jumlah anakan, jumlah daun, bobot basah dan kering tajuk yang lebih tinggi dibandingkan satu bibit per polybag pada 16 MSP (Tabel 7). Hal ini disebabkan karena pertumbuhan tanaman dengan dua bibit per polybag masih cukup baik, sehingga total biomassa yang dihasilkan dari dua tanaman menjadi lebih tinggi dibandingkan dengan satu tanaman.

Tabel 7. Pengaruh jumlah bibit terhadap tinggi tanaman, saat muncul anakan pertama, jumlah daun, jumlah anakan, bobot basah dan kering tajuk total per polybag pada 16 MSP

\begin{tabular}{ccccccc}
\hline Jumlah bibit & $\begin{array}{c}\text { Tinggi } \\
\text { tanaman }(\mathrm{cm})\end{array}$ & $\begin{array}{c}\text { Saat muncul } \\
\text { anakan pertama } \\
(\mathrm{HST})\end{array}$ & $\begin{array}{c}\text { Jumlah } \\
\text { daun } \\
\text { (helai) }\end{array}$ & $\begin{array}{c}\text { Jumlah } \\
\text { anakan } \\
\text { (anakan) }\end{array}$ & $\begin{array}{c}\text { Bobot } \\
\text { basah } \\
\text { tajuk }(\mathrm{g})\end{array}$ & $\begin{array}{c}\text { Bobot } \\
\text { kering } \\
\text { tajuk }(\mathrm{g})\end{array}$ \\
\hline Satu bibit per polybag & 183.2 & 2.4 & 242.5 & 35.7 & 213.2 & 44.9 \\
Dua bibit per polybag & 188.8 & 2.6 & 335.3 & 50.8 & 281.2 & 60.3 \\
\hline Uji F & tn & tn & $* *$ & $* *$ & $*$ & $*$ \\
\hline $\begin{array}{l}\text { Keterangan: } * * \text { berbeda sangat nyata pada taraf } \alpha=1 \%, * \\
\text { berbeda nyata. }\end{array}$
\end{tabular}

Kagho dan Gardner (1988) menyatakan bahwa pada tanaman jagung yang memiliki bentuk tajuk tegak dalam suatu populasi tanaman persaingan dalam memperoleh cahaya masih dapat ditolerir sehingga laju fotosintesis untuk proses pembelahan sel dan pembentukan jaringan 
yang baru tidak terganggu. Tanaman akar wangi mempunyai bentuk tajuk yang relatif tegak sehingga tidak saling menaungi walaupun ditanam dengan jarak $10 \mathrm{~cm}$ antar tanaman. Oleh karena itu, diduga cahaya matahari masih dapat digunakan oleh masing-masing individu tanaman untuk proses fotosintesis secara optimal.

Penanaman dua bibit per polybag tidak menyebabkan penurunan jumlah anakan bila dibandingkan dengan satu bibit per polybag. Wangiyana et al. (2009) melaporkan bahwa jumlah daun per rumpun tanaman padi akan meningkat seiring dengan pertambahan jumlah anakan per rumpun tanaman. Setiap bibit akar wangi memiliki potensi untuk membentuk anakan, dimana anakan tersebut nantinya dapat membentuk anakan lagi. Wangiyana et al. (2009) juga menyatakan bahwa jumlah daun dan jumlah anakan padi berbanding lurus dengan bobot kering tanaman. Apabila semakin banyak jumlah bibit yang ditanam per polybag dapat meningkatkan pertumbuhan jumlah anakan yang semakin banyak, maka bobot kering tanaman yang dihasilkan juga akan tinggi. Oleh sebab itu, peluang terjadinya pertambahan jumlah anakan, jumlah daun, dan peningkatan biomassa lebih tinggi pada jumlah bibit yang lebih banyak dalam satu polybag. Hasil penanaman dua bibit per polybag merupakan pertambahan dua individu tanaman dalam satu polybag. Hal ini mengindikasikan adanya efisiensi input yang digunakan dalam penanaman apabila menggunakan dua bibit per polybag.

Tidak adanya hambatan pertumbuhan yang signifikan pada penanaman dua bibit per polybag juga ditunjukkan dengan kandungan klorofil a, klorofil b, klorofil total, karotenoid, dan antosianin daun tanaman akar wangi yang tidak berbeda dengan satu bibit per polybag (Tabel 8).

Tabel 8. Pengaruh jumlah bibit terhadap warna daun pada 7 MSP dan kandungan klorofil daun pada 6 MSP

\begin{tabular}{ccccccc}
\hline Jumlah bibit & $\begin{array}{c}\text { Warna } \\
\text { daun }\end{array}$ & $\begin{array}{c}\text { Klorofil } \\
\text { total }\end{array}$ & Klorofil a & Klorofil b & Karotenoid & $\begin{array}{c}\text { Antosianin } \\
\left(\mathrm{mmol} \mathrm{g}^{-1}\right)\end{array}$ \\
\hline Satu bibit per polybag & 41.4 & 2.5 & 1.8 & 0.7 & 0.4 & 0.4 \\
Dua bibit per polybag & 42.0 & 1.9 & 1.4 & 0.5 & 0.3 & 0.4 \\
\hline Uji F & tn & tn & tn & tn & tn & tn \\
\hline
\end{tabular}

Keterangan: Angka pada kolom yang sama yang diikuti huruf yang sama menunjukkan hasil yang tidak berbeda nyata berdasarkan DMRT pada taraf $\alpha=5 \%$. tn $=$ tidak berbeda nyata.

Penanaman dua bibit per polybag juga menghasilkan rata-rata jumlah akar besar, akar kecil, akar total, dan akar baru per individu tanaman yang lebih rendah dibandingkan pada penanaman satu bibit per polybag (Tabel 9).

Tabel 9. Pengaruh jumlah bibit terhadap jumlah akar besar, akar kecil, akar total, dan akar baru per individu tanaman pada $20 \mathrm{MSP}$

\begin{tabular}{ccccc}
\hline Jumlah bibit & Akar besar (unit) & Akar kecil (unit) & Akar total (unit) & Akar baru (unit) \\
\hline Satu bibit per polybag & 92.7 & 44.0 & 147.0 & 10.3 \\
Dua bibit per polybag & 62.8 & 34.1 & 106.9 & 10.6 \\
\hline Uji F & $* *$ & $*$ & $* *$ & tn \\
\hline Keterangan: ** = berbeda sangat nyata pada taraf $\alpha=1 \%, *$ = berbeda nyata pada taraf & $\alpha=5 \%$, tn = tidak \\
&
\end{tabular}

Ruang tumbuh satu bibit per polybag lebih luas dibandingkan dengan dua bibit per polybag sehingga perkembangan akar individu tanaman pada perlakuan satu bibit per polybag lebih tinggi. Sebaliknya, pada perlakuan dua bibit per polybag terjadi persaingan ruang tumbuh akar dan penyerapan hara di dalam media dan mengakibatkan hambatan dalam pertumbuhan akar.

Walaupun terdapat persaingan ruang tumbuh akar, penanaman dua bibit per polybag dapat menghasilkan total biomassa yang lebih tinggi dibandingkan dengan penanaman satu bibit per polybag. Penanaman dua bibit akar wangi per polybag menghasilkan jumlah akar besar, akar 
kecil, dan akar total tanaman akar wangi yang lebih tinggi dibandingkan satu bibit per polybag pada 20 MSP (Tabel 10). Jika jumlah akar diakumulasikan dari dua individu tanaman pada perlakuan dua bibit per polybag, maka jumlah akar pada perlakuan tersebut lebih tinggi dibandingkan dengan penanaman satu bibit per polybag. Penanaman dua bibit per polybag dapat menghasilkan jumlah akar per polybag yang lebih tinggi sehingga dapat meningkatkan produksi akar per satuan luas.

Tabel 10. Pengaruh jumlah bibit terhadap jumlah akar besar, akar kecil, akar total, akar baru, panjang akar, dan diameter akar total per polybag pada 20 MSP

\begin{tabular}{ccccccc}
\hline Jumlah bibit & $\begin{array}{c}\text { Akar besar } \\
\text { (unit) }\end{array}$ & $\begin{array}{c}\text { Akar kecil } \\
\text { (unit) }\end{array}$ & $\begin{array}{c}\text { Akar total } \\
\text { (unit) }\end{array}$ & $\begin{array}{c}\text { Akar baru } \\
\text { (unit) }\end{array}$ & $\begin{array}{c}\text { Panjang } \\
\text { akar (cm) }\end{array}$ & $\begin{array}{c}\text { Diameter } \\
\text { akar (cm) }\end{array}$ \\
\hline Satu bibit per polybag & 92.7 & 44.0 & 147.0 & 3.2 & 124.0 & 19.7 \\
Dua bibit per polybag & 125.7 & 68.1 & 213.9 & 4.6 & 140.8 & 17.1 \\
\hline Uji F & $* *$ & $* *$ & $* *$ & tn & tn & tn
\end{tabular}

Keterangan: $* *=$ berbeda sangat nyata pada taraf $\alpha=1 \%, \mathrm{tn}=$ tidak berbeda nyata.

\section{KESIMPULAN}

Tanaman akar wangi yang ditanam pada media arang sekam : styrofoam (1:1) memiliki jumlah daun, jumlah anakan, jumlah akar, panjang akar, kandungan klorofil dan karotenoid yang lebih tinggi dibandingkan tanaman yang ditanam pada media arang sekam $100 \%$ dan arang sekam : styrofoam (2:1). Penanaman dua bibit per polybag menghasilkan jumlah daun, jumlah anakan, bobot basah dan kering tajuk, dan jumlah akar yang lebih tinggi dibandingkan dengan satu bibit per polybag. Hasil tersebut menunjukkan bahwa penanaman dua bibit per polybag pada media arang sekam : styrofoam (1:1) menghasilkan pertumbuhan vegetatif dan pertumbuhan akar terbaik pada tanaman akar wangi.

\section{DAFTAR PUSTAKA}

Ermina. 2010. Media tanaman hidroponik dari arang sekam [Internet]. [diunduh $5 \mathrm{Mei}$ 2012]. Tersedia pada: http://www.bbpplembang.info/.

Ginting B. 2008. Membuat media tumbuh anggrek. Sinar Tani. KP Penelitian Tanaman Hias:4

Handoko. 2009. Unsur-unsur cuaca dan iklim. Di dalam: Erizal, Ibnul Q, Utomo K, editor. Kumpulan Makalah Pengantar ke Ilmuilmu Pertanian. Bogor (ID): IPB Pr.

Hardjanti S. 2005. Pertumbuhan setek adenium melalui penganginan, asal bahan setek, penggunaan pupuk daun dan komposisi media. Agrosains. 7(2):108-114.
Kagho FT, Gardner FP. 1988. Respones of maize to plant population density. J Agron. 80(6):930-935.

Kardinan A. 2005. Tanaman Penghasil Minyak Atsiri. Tanggerang (ID): Agromedia.

Kartasapoetra AG. 2008. Klimatologi: Pengaruh Iklim Terhadap Tanah dan Tanaman. Jakarta (ID): Bumi Aksara.

Li R, Guo P, Baum M, Grando S, Ceccarelli S. 2006. Evaluation of chlorophyll content and fluorescence parameters as indicators of drought tolerance in barley. Agricultural Sciences in China. 5(10):751-757.

Mulyati H, Setiawan A, Rusli M. 2009. Rancang Bangun Sistem Manajemen Rantai Pasokan dan Risiko Minyak Akar Wangi Berbasis IKM di Indonesia. Bogor (ID): Institut Pertanian Bogor.

Mulyono E, Sumangat D, Hidayat T. 2012. Peningkatan mutu dan efisiensi produksi minyak akar wangi melalui teknologi penyulingan dengan tekanan uap bertahap. Bul Teknol Pascapanen Pert. 8(1):35-47.

Prihastanti E. 2010. Kandungan klorofil dan pertumbuhan semai kakao (Theobroma cacao L.) pada perlakuan cekaman kekeringan yang berbeda. BIOMA. 12(2):35-39.

Resh HM. 2004. Hydroponics Food Production. New Jersey (US): Newconcept Pr.

Sani. 2011. Minyak dari Tumbuhan Akar Wangi. Surabaya (ID): Unesa University Pr. 
Santoso A, Widodo S, Ma'arif F. 2011. Pemanfaatan limbah styrofoam untuk pembuatan dinding ringan struktural dengan perkuatan kawat kassa. J Inersia. 7(1):1-18.

Sims DA, Gamon JA. 2002. Relationship between leaf pigment content and spectral reflectance across a wide range of species, leaf structures anddevelopmental stages. Remote Sensing of Environtment. 81:37354.

Song H. 2005. Effect of VAM on host plant in the condition of drought stress and its mechanisms. J Biol. 1(3):44-48.

Surtiningsih. 2009. Mengenal lebih dekat rumput vetiver. Bul BPKSDM. 2:16.
Suryanto A, Dwi WS. 2010. Modul Praktikum Dasar Budidaya Tanaman. Malang (ID): Brawijaya University Pr.

Tjasyono B. 2004. Klimatologi. Bandung (ID): Penerbit ITB. Ed ke-2.

Wangiyana W, Laiwan Z, Sanisah. 2009. Pertumbuhan dan hasil tanaman padi var. Ciherang dengan teknik budidaya SRI (System of Rice Intensification) pada berbagai umur dan jumlah bibit/lubang tanam. Crop Agro. 2(1):30-42.

Yoshida S, Forno DA, Cook JH, Gomez KA. 1979. Manual for Physiological Studies of Rice. Los Banos (PH): IRRI. 